\title{
THE WHITE VEINS: CONCEPTUAL DIFFICULTIES IN THE HISTORY OF THE LYMPHATICS*
}

by

\author{
REGINALD S. A. LORD
}

RECOGNITION of the true nature of the lymphatics depended upon the realization that, despite inter-relations, these vessels were different from veins. This realization evolved slowly. It commenced with sporadic observations by the ancients of the existence of vessels of similar dimensions to small veins but of different appearance. These early references to lymphatics were neglected for about 2,000 years.

With the Renaissance, interest in the lymphatics was revived, spurred initially by accidental discoveries of lymph vessels loaded with chyle. Deliberate studies soon followed, making possible a coherent account of the ramifications of the system.

Techniques which had been successfully applied to related disciplines were now turned to the study of the new vessels; notable in this connection were microscopy and intravascular injections. The latter, albeit much modified, have been employed in researches on the lymphatics ever since.

The ability to distinguish lymphatics and veins on an anatomical and distributive basis was soon established. However, while their function remained obscure it was possible to regard lymphatics as merely another sort of vein. This conception was widely held despite serious objections until well into the eighteenth century. The Hunterian School of Anatomy finally dissipated this notion with the demonstrations of the absorbing capacity of the lymphatics.

From then onwards the differences between lymphatics and veins were widely realized. There remained only the problems of clarifying the precise relations of the two systems, a task still incomplete as modern investigators dispute the existence and raison d'être of lympho-venous communications.

\section{EARLIEST REFERENCES}

Lymphatics were observed long after the rest of the vasculature was known to exist. Their smallness and transparency were principally responsible for this delay, although early references to their existence were neglected as the significance of these tiny vessels was not realized.

Aristotle (384-322 B.C.) is said to have described structures containing colourless fluid which could have been lymphatics. Likewise, there are passages in the books ascribed to Hippocrates which may refer to lacteals, the following being the most suggestive: 'There are also in the body, veins from the stomach, very small, and of all kinds, by whose means the food comes into the body'.

However, it is difficult to know which vessels Hippocrates was describing in this quotation as Cruikshank commented in 1786: 'Hippocrates . . . could not mean the real absorbents: no vessels different from arteries and veins are easily to be seen

*Maccabaean Prize Essay, 1967. 


\section{The White Veins}

there. The lymphatics of the stomach are found with very great difficulty as they never, like the lacteals, carry an opaque fluid'.

Unequivocal references to lacteals came first from Alexandria. This famous medical school had adopted traditional Hippocratic teachings although these beliefs were not shared by all. The dissenters included Erasistratus (c. 310-250 B.C.) who was fundamentally antagonistic to the 'Corpus Hippocratium' (Mettler and Mettler, 1947). Erasistratus, who has been described as the 'Father of Physiology' (cf. Dobson, 1927), experimented to support his objections to the Hippocratic theories of digestion. Celsus claimed that Erasistratus included human vivisection amongst his other dissections. The original works of Erasistratus have been annotated by Galen who quotes the following passage: 'For on dividing the epigastrium and along with it the peritoneum, we may see arteries, on the mesentery of sucking kids, full of milk'.

Herophilus (335-280 B.C.) was Erasistratus's great rival and contemporary at Alexandria. He noted the presence of lymphatic glands as well as lacteals: 'For, in the first place [Nature] has made, in the whole of the mesentery, peculiar veins, destined for the nourishment of the intestines, not passing to the liver for, as Herophilus says, these veins terminate in certain glandular bodies, whilst all the rest are carried upwards to the portae [liver].'

It is possible that both these descriptions of mesenteric lymphatics were based on observations of the living as alleged by Celsus. Certainly lacteals are more readily discernable in living man than in cadavers.

Galen, in preserving these telling excerpts from the works of both Herophilus and Erasistratus, was clearly aware of the existence of lacteals and mesenteric nodes. Marinus (fl. A.D. 50) had also described mesenteric nodes.

\section{INFLUENCE OF THE RENAISSANCE}

Galen enjoyed supreme authority until well into the Renaissance. During the period of his influence little further thought was given to the lymphatics. Anatomy in general advanced slowly until the latter half of the sixteenth century when the important anatomical discoveries of the age embroiled many in disputation. The opportunity to dissect and personally verify the new findings became more freely available, although this privilege was by no means universal. A new era characterized by experimentation and dissection had supervened over the preceding centuries of unchallenged dogma. Timely technical assistance was provided by the recently introduced aids to dissection, such as magnification by lenses and injections to delineate fine vessels. Rediscovery of the lymphatics could be deferred no longer.

Fallopius (1561) mentioned mesenteric veins containing yellow matter but it was a critic of Vesalius who properly inaugurated the rediscovery of the lymphatics. Eustachius (1520-1574) held the Chair of Anatomy at Rome at the time of the great anatomical controversies. He successfully managed to accept traditional Galenical teaching while engaged in many original investigations and dissections. In 1563 Eustachius published his Treatise de Vena sive pari. Herein is described his discovery and description of the thoracic duct (vena alba thoracis) of a horse. Eustachius was able to find the termination of the duct in the left subclavian vein but not the inferior connections. Not surprisingly he could give no clue to the function of the duct. 


\section{Reginald S. A. Lord}

The next great advance in the history of the lymphatics had to wait almost another sixty years. On 23 July 1622 Gaspar Aselli while studying the diaphragm of a living dog which had just eaten a fatty meal, discovered the lacteals afresh. He named them 'venae albae et lacteae' (from lactis, intestine; not lac, milk). Aselli traced the lacteals to a glandular mass (pancreas Aselli) lying on the edge of the mesentery in the dog. From here he considered they drained to the liver (fig. 1), The authority of Galen precluded Aselli from conceiving that ingested alimentary contents would pass to sites other than the liver. Indeed for the necessary 'concoction' into blood the liver was essential and this is the probable explanation of his error.

Aselli realized the absorptive nature of his 'venae albae' by recognizing their chylous contents. He can logically be considered to have begun the process of differentiating lymphatics from veins. Subsequently Aselli saw lacteals in a variety of other quadrupeds but not in man. Haller (1774) stated that about 1600 the Republic of Pavia, where Aselli was Professor of Anatomy, omitted even the public dissection from parsimony so that Aselli had no access to human material. Aselli reasoned analogously that lymphatics existed in man but did not prove this assertion. His publication De lactibus sive lacteis venis appeared in 1627, the year before Harvey's De motu cordis. Soon after Aselli's discovery, lacteals were first seen in man by Brechet (1628) according to Skavlem (1921).

In 1634 Johann Vesling of Padua also confirmed the presence of lacteals in man. His Anatomy of the Body of Man was published posthumously in 1653 and contains the earliest illustrations of human lymphatics (fig. 2). Vesling's papers were apparently entrusted to Thomas Bartholin and it is possible that this was the initial stimulus to Bartholin's scientific investigations of the lymphatics (Skinner, 1949).

Jean Pecquet of Dieppe in 1649 gave the preliminary hints to the understanding of the thoracic duct when he described its subdiaphragmatic course to the cisterna chyli. Following excision of the heart of a live dog he had observed milk-like fluid coming from the superior vena cava. From the subclavian vein he traced the thoracic duct or ducts inferiorly to a dilatation under the diaphragm. Pecquet also described how the contents of the lacteals emptied into this dilatation ('receptaculum chyle'). He further noted connections between his newly discovered cistern and the inferior vena cava. Injection studies led Pecquet to believe that these communications were patent and he has been hailed as the first to find lymphovenous communications although it is likely that his connections were fibrous and possessed no lumen (Limborgh, 1964). At much the same time further observations on the lymphatics were being made by Thomas Bartholin, Olof Rudbeck and George Joliff.

About Joliff's life and work little is known. He was born about 1618, took the Oxford M.A. on 29 April 1642 and later the Cambridge M.D. (Bliss, 1820). From the Athenae Oxoniensis, 1817, we learn that: 'exercising himself much in anatomy, with the help of Dr. Clayton master of his college and the King's professor of physic, he made some discovery of that fourth sort of vessels, plainly different from veins, arteries and nerves, now called the lympheducts. Afterwards he went to Clare Hall in Cambridge, took the degree of doctor of physic there and afterwards made a full and open discovery of the said vasa lymphatica in anatomy lectures in the college of physicians'. Joliff apparently made no further contributions to academic medicine; 


\section{The White Veins}

instead, by the age of thirty-five, he carried on an extensive clinical practice. Both his lectures to the college of physicians and his doctoral thesis are lost so that his work remains an enigma. He died in 1658 (Munk, 1878) in his fortieth year. His later years were troubled as he had been bound for the debts of his brother (Athenae Oxoniensis, 1817), and maybe pecuniary embarrassment was partially responsible for his exchanging anatomy for more lucrative pursuits.

None of Joliff's work is extant but his contribution, although little published, must have been significant. Possibly it antedated the work of Rudbeck and Bartholin. In the Philosophical Transactions of 1668 Dr. Timothy Clarke states that Joliff discovered the lymphatics before 1652. In De Hepate of 1654 Francis Glisson referred to Joliff's work on liver lymphatics. Again, Frederick Ruysch on lymphatic valves (1665) gave Joliff an honoured place: 'Bartholinus, Rudbeckius, Jolivius, Sylvius, van Horne \& alii ante me (quanquam non ita dilucide) in lymphaticis observarunt valvulas'.

Olof Rudbeck of Uppsala, according to his own account, began his lymphatic studies in 1650 . On this occasion he noticed a milky fluid near the supraclavicular notch of a slaughtered calf. Rudbeck defined the thoracic duct and traced its lower end to a bladder-like structure near the abdominal aorta. Unaware of Pecquet's work, Rudbeck called this dilatation the 'Vesicula Chyli'.

In 1651 while dissecting a cat Rudbeck showed that lacteals, cisterna chyli, thoracic duct and termination of the latter in the great veins of the neck were a continuous system (fig. 3). So far he had accomplished no more than Pecquet.

In April 1652 Rudbeck demonstrated his experiments to Queen Christina of Sweden and on this occasion learned of Pecquet's results. Not long after, he read of similar findings by van Horne and Bartholin. In 1653 his results were published in his Nova Exercitatio Anatomica. He had dissected nearly 400 animals in the preceding three years and discovered lymph vessels in the rectum (1651), oesophagus (1651), leg (1652) and posterior surface of the sternum (1653). His description of the appearance of lymphatic vessels was accurate:

'On 6 March 1652 . . . I observed . . . numerous vessels, transparent, nodular, swollen with serum, covering the surface of some glands alongside the crural veins, and running towards the chyle vesicle'. (Neilsen, 1942). Employing a ligature technique and reasoning with logic similar to that used by Harvey in connection with the blood, Rudbeck established the direction of flow of intra-abdominal lymph. In 1652 he demonstrated that lymph does not flow towards the liver thus negating a doctrine which had vague origins at about the time of Herophilus. His results concerning hepatic lymph flow were supported by Francis Glisson (1654).

Thomas Bartholin (1616-1680) held the Chair of Anatomy in Copenhagen at the time when his important publications on lymphatics appeared. The earliest was De lacteis thoracicis in homine brutisque in 1652. His findings, similar to those of Pecquet, include a diagram of the cisterna chyli in man which is essentially accurate. His further papers set forth discoveries comparable to those of Rudbeck. Bartholin enjoyed royal patronage at the time of his lymphatic investigations and his anatomical dissertations received wide publicity. His fame and authority were responsible for the adoption of his term 'vasa lymphatica' rather than the 'vasa serosa' of Rudbeck.

Bartholin's work and conclusions were essentially similar to those of Rudbeck. 
Independently each demonstrated the ubiquity of lymphatics in the human body and realized the generality of this system which embraced the cisterna, thoracic duct, mesenteric lacteals and peripheral lymphatics. Each advanced the concept of a system disparate from the veins and each thereby contributed to our comprehension of the nature of the lymphatics. It was their work, pre-eminent amongst that of other interested contemporaries, which led to general acceptance of a 'fourth sort of vessel' (the third being nerves).

This coincidence in their findings, as in other instances of identical coeval discoveries, led to mutual accusations of plagiarism. Protagonists for both parties made exclusive claims for the discovery of the systematic nature of the lymphatics (cf. Fulton, 1938; Gans, 1962), and at times seemed to forget the contributions of their predecessors. The situation could be judiciously epitomized by saying that Rudbeck was first to experiment, Bartholin first to publish.

This dispute over primacy at least had the virtue of disseminating what was then known about lymphatics and these facts were largely accepted by other medical men of the time. Harvey was a notable exception (Foster, 1901).

Frederick Ruysch (1638-1731) was stimulated in this way and in 1665 published his Dilucidatio valvularum which contained a description of the morphology and function of lymphatic valves and was clearly illustrated (fig. 4). The lymphatic valves were naturally compared with those in the veins. Ruysch had been a pupil of Jan Swammerdam and both men typified the skill of Dutch anatomists in the handling of fine structures. Swammerdam was a celebrated microscopist while Ruysch had devised a new method of intravascular injections with a solidifying waxy medium (Hazen, 1939). Although he used this technique in a study of the minute blood vessels of the skin and the lungs it is not clear whether intralymphatic injections were employed by Ruysch. Ruysch controlled his delicate intravascular injections with the microscope and it is credible that this was a harbinger of modern lymphangiography (Kinmonth, 1954).

At the close of the seventeenth century the existence of the lymphatics was widely acknowledged. Clues to their absorptive function had been given by Aselli, Glisson, Rudbeck and others but proof was lacking and the lymphatics were a curiosity. Paradoxically Harvey, trenchant in his criticism of the evidence of Aselli and Rudbeck, denied the implications of their findings.

Injection methods were widely practised, often in the case of the lymphatics without the care which their delicate structure demanded. Artefacts resulted and the distinction from the venous system was in danger of becoming unclear.

\section{THE EIGHTEENTH CENTURY}

The next important works in the history of lymphatic discovery came from the Hunters' Anatomy School in Windmill Street (Dobson, 1955). From here William Hunter proposed that: 'a grand system for absorption, in men and quadrupeds, was formed, and the lacteals and lymphatics were blended under the common name of absorbents' (Cruikshank 1786).

A major objection to this absorption theory was the belief that lymphatics were not generally found in the animal kingdom. William Hewson of Hexham (1739-1774) 


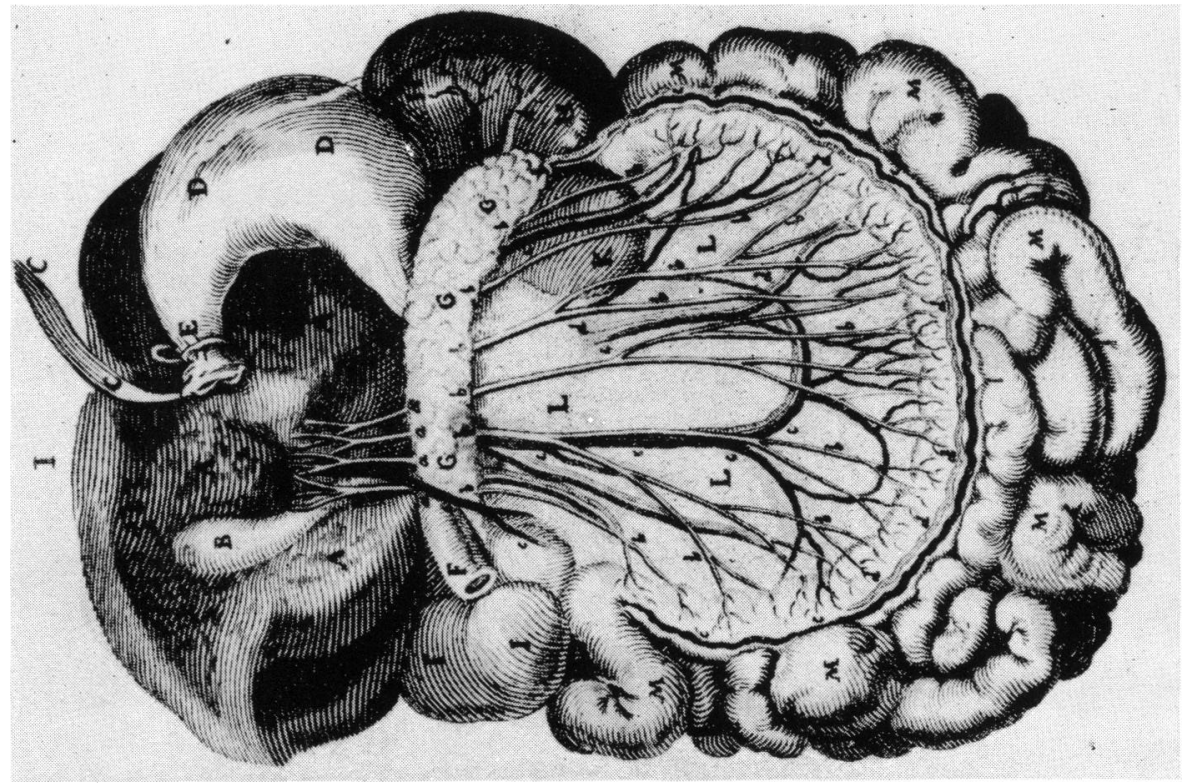

톤

ร...

ริ

ธ

ํㅗㅇㅝㅕㄴ

ฐิ

जे

i 000

牙

江 क

葛垔

ช๊

ำ

ङำ

可访

胥胥

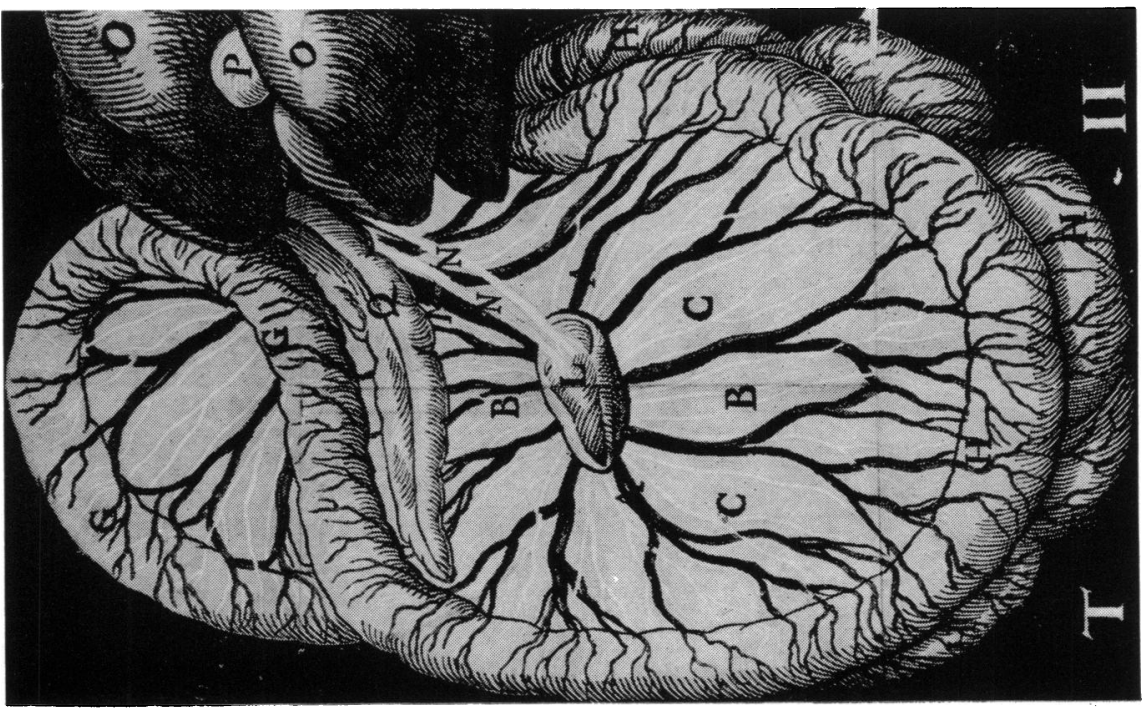

:

อั. ํํㄹ

ต 증후

응

-

농

我

矛近 O $\mathrm{i} \cdot$

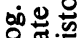
称空 ธิ 느 ङ 导蛋 


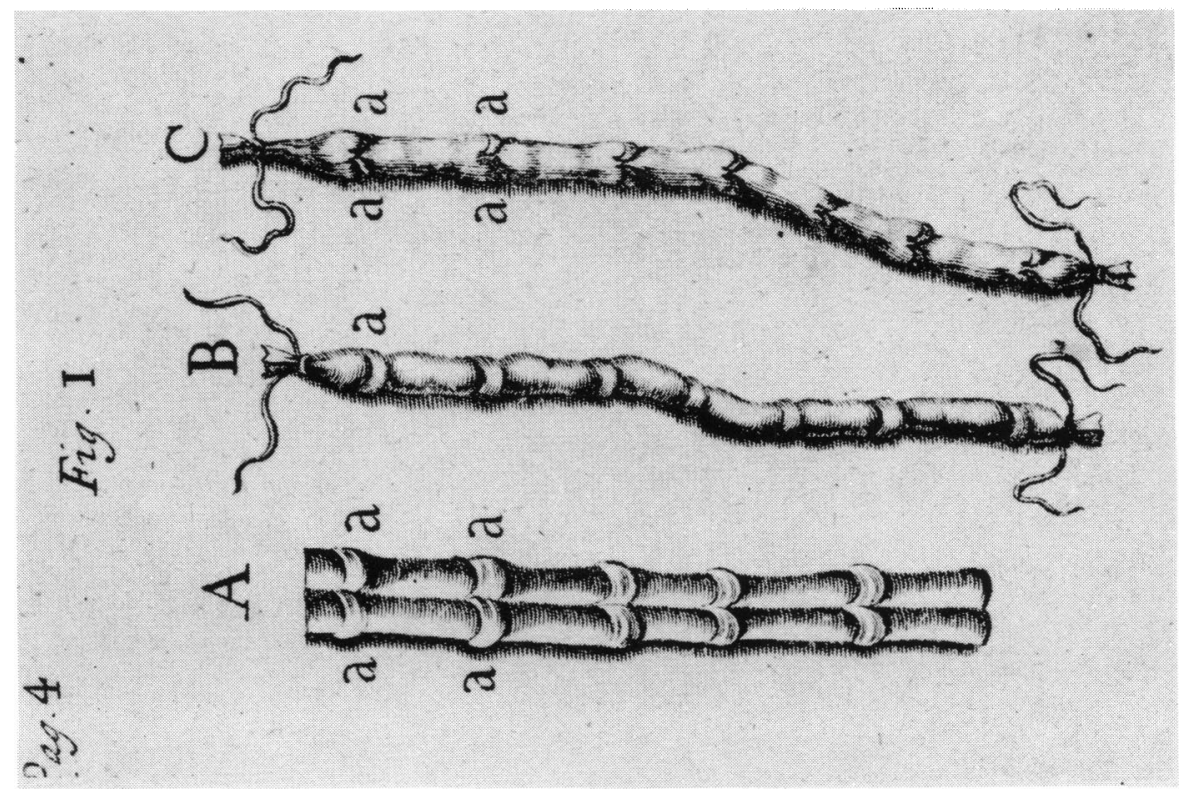

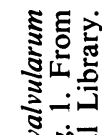
oge बु ิํํ리 ㅎำ

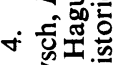

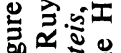
要 究 出 0 政 का 政 형 政

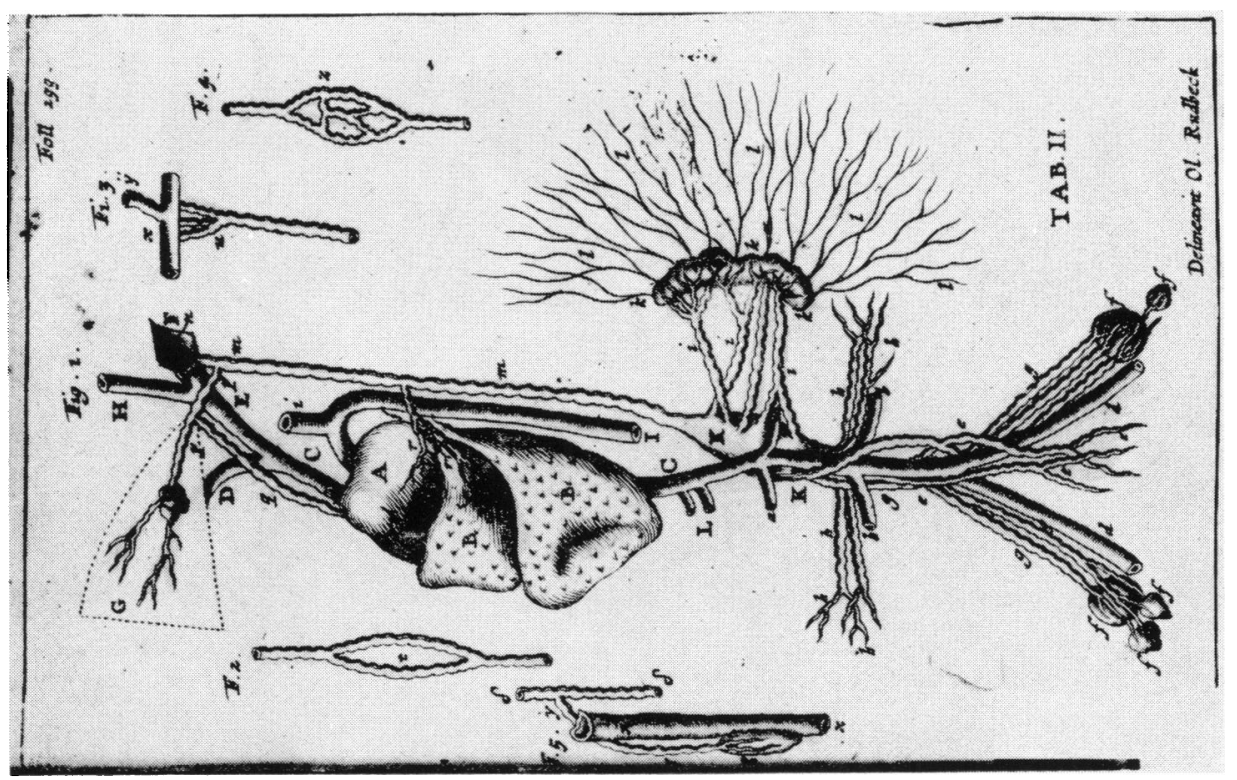

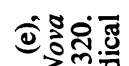
年

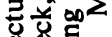
बु. 원.

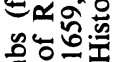
틍으웅 的实安要

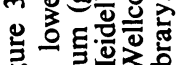

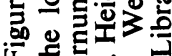

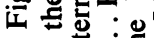
它: ำ 施客 들. 응

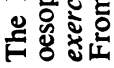




\section{The White Veins}

who succeeded John Hunter, answered this criticism in his Experimental Inquiries (1774). Part the Second of this book deals with the comparative morphology of lymphatics in mammals, birds, fishes and reptiles. Hewson observed that lymph glands were absent in fishes, rudimentary in birds and well developed in mammals. Lymph vessels, however, were present in all the vertebrates examined. Hewson is credited with noting the occurrence of lymphocytes in lymph and he believed that this indicated their origin from lymph nodes (Yoffey and Courtice, 1956). Hewson also classified human lymphatics into superficial and deep groups and depicted these accurately in his illustrations.

Injections of mercury and coloured dyes were used to aid his lymphatic studies: 'I formerly laid before the Royal Society a haddock with its lymphatics and bloodvessels filled with coloured injections' (Experimental Inquiries, p. 98). His technique for filling these lymphatics with dye does not differ greatly from modern methods. For example, writing about the lymphatics of fishes: 'The readiest way of finding the whole system is, to look for one of the vessels which lie close to the skin . . . and if a pipe be introduced, the whole system may be filled by its means.' (Experimental Inquiries, p. 97).

Hewson had previously been involved in a bitter controversy with Alexander Monro Secundus over alleged plagiarism and he was now accused of further appropriating Monro's material (Bailey, 1923). Monro claimed priority for many of Hewson's discoveries adducing the exhibition of injected specimens to anatomy classes as evidence of his interest in lymphatics e.g. 'About four years ago I injected the lacteal vessels of a turtle, or sea tortoise, with quicksilver, after injecting the artery and vein with wax' (letter to Dr. Donald Monro, 1769).

As was the case a century earlier the interest generated by this dispute at least promulgated the best opinions on the lymphatics so that Hewson was able to pronounce that 'the doctrine that the lymphatics .... were absorbents ... has been revived by Dr. Hunter and Dr. Monro' (Experimental Inquiries, 1774). In spite of this generous statement there is little evidence of originality in Monro's contribution to this subject.

Hewson was succeeded as Hunter's assistant by William Cruikshank (1745-1800). Cruikshank improved Hewson's classification of the lymphatics of man and gave accurate accounts of both regional lymph drainage and lymphatic topography, although his illustrations were excelled by those of Paolo Mascagni (1787). By means of diffusion studies Cruikshank was able to demonstrate the ability of the lymphatics to absorb and together with Hewson and William Hunter was responsible for dispelling much of the confusion surrounding the lymphatics. Cruikshank also found time to engage in a busy practice which included Dr. Johnson amongst his patients.

As a result of their researches the Hunterian school considered the lymphatics to form a unique system of absorbing vessels. They imagined these vessels to be closed peripherally and to have no communications with the rest of the vasculature other than at the usual sites of major lympho-venous confluence in the neck. The school did not permit to pass unchallenged the prevalent theories that lymphatics were continuations of small arteries or that they arose from serous or other cavities by open-ended tubes. William Hunter (1762) claimed that these hypotheses resulted from 


\section{Reginald S. A. Lord}

faulty injection methods. In this belief he was supported by Haller (1741) and Mascagni (1787). Mascagni well understood the difficulties, since his own intralymphatic injections were preceded by preliminary diffusion of gelatine from neighbouring arteries and veins into the lymphatics. In a similar way Cruikshank observed diffusion of coloured dyes from the gut to the lacteals.

Nuck (1692) and Meckel (1772) were amongst those who described apparent lymphovenous connections but the weight of the evidence was against them. The authority and fame of the Hunterian School publicized the absorption theory which became accepted almost universally.

The hypothesis that the terminal lymphatics were closed was finally vindicated in the late nineteenth century by Ranvier (1897) and confirmed by MacCallum (1903) and Clark (1909) all of whom used injection techniques. This confirmation succeeded an earlier misleading report by von Recklinghausen (1862) who considered that the lymphatics communicated directly with the tissue spaces. Von Recklinghausen's opinion concerned only a minor argument compared with the general truth established by the Hunterian school and his conclusions detracted but little from general acceptance of this theory.

Meanwhile better understanding of the nature of malignant disease was bringing another aspect of the lymphatics into prominence. Le Dran (1685-1770) first described the spread of cancer by the lymphatic route and John Hunter was one of the earliest to appreciate the importance of this (Dobson, 1959). Astley Cooper (1840), applying these principles to mammary cancer, investigated the lymphatics of the breast with mercurial injections and laid the foundations of modern methods of extirpative surgery.

Virchow (1860) complemented these studies of tumour dissemination by drawing attention to the defensive role of lymph glands in the formulation of his celebrated 'Barrier Theory', which accounted for the arrest of bacteria and particulate matter in lymph nodes and later was invoked to explain malignant lymphatic metastases.

Elucidation of the physiology of the fluid content of the lymph was achieved somewhat later when Starling (1894) enunciated his hypothesis of fluid exchange across capillary membranes. The participation of the lymphatics was integral to this theory; a distinction between the absorptive functions of lymphatics and veins was now possible, so that the exclusiveness of the Hunterian doctrines was revealed.

\section{LYMPHOVENOUS COMMUNICATIONS-A MODERN PROBLEM}

From the nineteenth century onwards the gross anatomy of the lymphatics has been largely settled and their individual nature is no longer questioned. In particular it has been widely held that the lymphatic vessels and veins communicate only in the neck in the region of the junction of the subclavian and jugular veins. Nevertheless there have been intermittent reports which suggest that these presently accepted beliefs ought perhaps be revised.

Fohmann (1821), investigated the comparative anatomy of the lymphatic system. He described direct communications between the peripheral veins and the lymphatics in birds, seals, otters, cats, dogs, horses, cows, and man. The existence of these connections was denied by S. T. von Soemmerring whose objections were based on 
the charge of injection artefacts. Leaf, in communications to the Lancet (1898, 1900), also claimed to have seen lymphovenous connections in man, but Bartels (1909), who was elaborating improved injection media, again denied their existence.

In 1912 Silvester published an account of lymphovenous anastomoses in South American monkeys although he could not demonstrate them in Old World monkeys. This study was both detailed and painstaking so that the perhaps justifiable criticisms directed at Fohmann, Leaf and their predecessors no longer applied. Of particular importance were the observations that the connections were species specific and that they were part of the normal lymphatic anatomy of the South American monkey. Job (1918) found similar communications in the rat, involving the renal and portal veins as well as the inferior vena cava. Neither the findings of Silvester nor of Job aroused much interest and they were easily explained as specific variants of comparative morphology.

Sabin (1913) laid the embryological foundation for such beliefs in a series of brilliant injection studies of the embryo, and her work was substantiated by Huntingdon and McClure (1908). These investigations established the existence of two sets of paired lymph sacs, jugular and iliac, which arose from the regional veins. Significantly the lymph sacs were at the same site as the reported lymphovenous communications. Pick (1944) recorded a case in which a directly observable lymphatic connection to an anomalous renal vein was found in man and he also invoked this embryological explanation.

In 1922 Lee described fistulous connections between lymphatics and the lumbar veins after experimental obstruction of thoracic duct in the domestic cat and similar results obtained in other animals with later investigators (Blalock et al., 1937; Belan et al., 1963; Neyazaki et al., 1965). There is now evidence of lymphovenous communications in most of the mammals so far studied even if these connections are only present in pathological states. Whether the communications are normally present but can only be demonstrated in circumstances of raised endolymphatic pressure or whether they are a response to raised pressure alone is uncertain. So far they do not admit of direct observation but have been inferred as result of laboratory experiments or indirectly visualized by lymphangiography which is dependent on intralymphatic injections (Kinmonth, 1954).

In man lymphovenous communications have never been directly observed except in the case reported by Pick (1944) which is presumed to be an example of atavistic regression. The plight of the modern investigator can be compared to that of Aselli since suitable experiments are limited to animals. The postulated communications in normal man have so far been too elusive for direct vision and final proof of their existence is lacking. Even their demonstration by lymphangiography may merely represent the persisting problem of artefacts caused by faulty injection techniques. The need for resolving this difficulty is illustrated by the advent of potentially hazardous forms of treatment such as endolymphatio radiotherapy (Jantet, 1958). The solution may also give a clearer understanding of the mechanisms of spread of malignant tumours from the lymphatics to the blood stream. In addition insight may be gained into the ultimate causes of oedema. 


\section{SUMMARY AND CONCLUSIONS}

In the earliest times it was necessary to differentiate the lymphatics from the veins for their separate existence to be suspected. They naturally aroused little interest until the conditions of the Renaissance led to their rediscovery.

The presence of the major anastomoses with the veins in the neck and the totality of the system which connected the lacteals and lymphatics to the thoracic duct simultaneously both delineated the new system and provided strong clues to its physiological role. Further advances followed the proof of the capacity of absorption of internally administered substances by the lymphatics. The system of absorbents was thus demonstrated and the idea that lymphatics were much the same as veins became untenable.

A major factor in this proof was the use of injection studies, which although responsible for many of the advances were also associated with the frequent production of artefacts. These artefacts initially were used as evidence to support contentions that lymphatics and veins were identical in essence. Later injection artefacts were claimed to prove the existence of lymphovenous communications.

The problem of defining the inter-relations of veins and lymphatics is still uncompleted. It has been complicated by the embryological findings that the lymphatics arise from the primitive veins and that some of these early lymph sacs persist in other species. The presence of indubitable lymphovenous communications in some animals can be explained on this basis.

The argument is not directly applicable to man except in the isolated case of atavistic regression. All the reported lymphovenous communications in living man were indirectly witnessed by lymphangiography and they have never been seen in normal man. The problem of artefacts remain.

A closer identity between the veins and the lymphatics may soon be permissible. From a common origin they differentiate along parallel pathways. The future alone will reveal whether these paths ever cross.

\section{REFERENCES}

Aristotle, cited by Rusznyak, L., Foldi, M., and Szabo, G., Lymphatics and Lymph Circulation, London, Pergamon Press, 1960.

AseluI, G., De Lactibus Sive Lacteis Venis, Quarto Vasorum Mesaraicorum Genere, 1627.

BAILEY, G. H., 'William Hewson, F.R.S. (1739-1774), an account of his life and work', Ann. Med. Hist., 1923, 5, 209.

Bartels, P., 'Das Lymphefassystem', in Bardeleben, Handbuch der Anatomie des Menschen, Jena, Fisher, 1909.

Bartholin, T., Vasa Lymphatica, nuper Hafniae in animalibus inventa et Hepatis Exsequiae, Paris, 1653. Cited by Hemsterhuy, S, in Messis Aurea, Heidelberg, 1659.

Belan, A., MALEK, P., and KolC, J., 'Rontgenkinematographischer Nachweis Lymphovenoser Verbindungen im Versuch in Vivo', Fortschr. Rontgenstr., 1963, 99, 168.

Blalock, A., Robinson, G. S., Cunningham, R. S., and Gray, M. E., 'Experimental studies on lymphatic blockage', Arch. Surg., 1937, 34, 1049-71.

Buss, P., Fasti Oxonienses, London, Rivington, 1815, p. 514.

Idem., Athenae Oxoniensis, London, R. Knaplock, 1817, vol. 3., p. 351.

Idem., Fasti Oxoniensis, London, Rivington, 1820, p. 57.

Celsus, De Medicina, A.D. 34, cited by Mettler and Mettler, 1947, p. 17. 


\section{The White Veins}

Clark, E. R., 'Observations on living growing lymphatics in the tail of the frog larva', Anat. Rec., 1909, 3, 183-98.

Clark, T., A letter in Phil. Trans., 1668, 3, 674.

COOPER, A., The Anatomy of the Breast, London, Longman, 1840.

Cruikshank, W., The Anatomy of the Absorbing Vessels of the Human Body, London, G. Nicol, 1786.

Dobson, J. F., 'Herophilus of Alexandria', Proc. Roy. Soc. Med., 1925, $18,19$.

Idem., 'Erasistratus', Proc. Roy. Soc. Med., 1927, 20, 825.

Idem., 'The Hunters and the absorbents', Ann. Roy. Coll. Surg. Eng., 1955, 16, 60-62.

Idem., 'John Hunter's views on cancer', Ann. Roy. Coll. Surg. Eng., 1959, 25, 176.

Eustachius, B., De Vena Sive Pari, Venice, 1563.

ERASISTRATUS, quoted by Galen per Cruikshank, 1786.

Fallopius cited by Castiglioni, A., A History of Medicine, edited and translated by E. B. Krumbhaar, New York, Knopf, 1941.

Fohmann, V., Anatomische Untersuchungen Uber die Verbindung der Saugadern mit den Venen, Heidelberg, 1821.

Foster, M., Lectures on the History of Physiology during the Sixteenth, Seventeenth and Eighteenth Centuries, Cambridge University Press, 1901.

Fulton, J. F., 'The early history of the lymphatics with particular reference to Bartholin, Rudbeck and Joliff', Bull. of the Hennepin County Medical Society, 1938, 9, 5.

GaLEN cited by Cruikshank, 1786.

GaNs, H., 'On the discovery of the lymphatic circulation', Angiology, 1962, 13, 530.

Guisson, F., De Hepate, London, 1654.

HAller, A. voN., Observationes de Ductu Thoracico in Theatro Gottinensi Factae (Haller's Disp. Anat. 1, 793), Gottingen, Vanderhoeck, 1741.

Idem., Bibliotheca Anatomica, Tiguri, 1774.

HAZEN, N. T., 'Johnson's life of Frederic Ruysch', Bull. Hist. Med., 1939, 7, 324.

HerophILus quoted by Galen per Cruikshank, 1786.

Hewson, W., Experimental Inquiries, London, Longman, 1774.

HIPPOCRATES cited by Cruikshank, 1786.

Hunter, William, Medical Commentaries, vol. 1, chap. 2: Of the Origin and use of the Lymphatic Vessels, London, 1762.

Huntingdon, G. S., and MCCluRe, C. F. W., 'The anatomy and development of the jugular lymph sacs in the domestic cat', Anat. Rec., 1908, 2, 1-18.

Jantet, G. H., Report to the Ninth Scientific Meeting, Surgical Research Society, London, 1958.

JoB, T. T., 'Lymphaticovenous communications in the common rat and their significance', Amer. J. Anat., 1918, 24, 467.

KINMONTH, J. B., 'Lymphangiography in clinical surgery and particularly in the treatment of lymphoedema', Ann. Roy. Coll. Surg. Eng., 1954, 15, 5, 300.

LEAF, C. H. 'The relation of blood to lymphatic vessels', Lancet, 1900, i, 606 (cites 1898 reference).

Le Dran, cited by Haagensen, G. D., Amer. J. Cancer, 1933, 18, 42.

LEE, F. C., 'The establishment of collateral circulation following ligation of the thoracic duct', Bull. Johns Hopk. Hosp., 1922, 33, 21.

LiMBORGH, J. vaN., 'Sur la nature des communications lymphatico-veineuses prévertébrales de Frautschi', Acta Anat., 1964, 56, 389-97.

McCallum, W. G., 'The relations between the lymphatics and the connective tissue', Bull. Johns Hopk. Hosp., 1903, 14, 1-9.

MARINus cited by Mettler \& Mettler, 1947 p. 21.

MASCAGNI, P., Vasorum Lymphaticorum Corporis Humani Historia et Ichnographia, Siena, Carli, 1787.

Meckel, J. F., Epistola ad Hallerum, Berol, 1772.

MetTler, C. M., and MetTler, F. A., History of Medicine, Toronto, Blakiston, 1947. 
Monro Secundus, A., (1769) cited by Hewson, 1774.

Munx, W., The Roll of the Royal College of Physicians of London, vol. 1, pp. 280-1, London, Royal College of Physicians, 1878.

Neyazaki, T., KupiC, E. A., Marshall, W. H., and Abrams, H. L., 'Collateral lymphaticovenous communications after experimental obstruction of the thoracic duct', Radiology, $1965,85,423$.

NIELSEN, A. E., 'A translation of Olof Rudbeck's Nova Excercitatio Anatomica (1653)', Bull. Hist. Med., 1942, 11, 304.

Nuck, A., Adenographia Curiosa et Uteri Foeminei Anatome Nova, Leyden, 1696.

PecQuet, J., New Anatomical Experiments by which the hitherto unknown receptacle of the Chyle and the transmission from thence to the Subclavial Veins by the now discovered Lacteal Channels of the Thorax is plainly made appear in Brutes, London, 1653.

Pick, J. W., ANson, B. J., and Burnetr, H. W., 'Communications between lymphatic and venous systems at renal level in man', Q. Bull. NWest. Univ. med. Sch., 1944, 18, 307.

RANviER, L., 'Morphologie et developpement des vaisseaux lymphatiques chez les mammifères', Archs Anat. microsc., 1897, 1, 69-81.

ReCkinghausen, F. von., Die Lymphagefasse und ihre Beziehung Zum Bindegewebe, Berlin, Hirschwald, 1862.

Rudbeck, Olof, Nova Exercitatio Anatomica Exhibens Ductus Hepaticos Aquosus et Vasa Glandularum Serosa, Lauringer, Vasteras, 1653.

RuYsch, F., Dilucidatio Valvularum in Vasis Lymphaticis et Lacteis, The Hague, 1665.

SABIN, F. R., The Origin and Development of the Lymphatic System, Johns Hopkins Press, Baltimore, 1913.

SilVESTER, C. F., 'On the presence of permanent communications between the lymphatic and venous system at the level of the renal veins in adult South American monkeys', Amer. J. Anat., 1912, 12, 447.

SkAvlem, J. H., 'The scientific life of Thomas Bartholin', Ann. med. Hist., 1921, 3, 67.

SkINNER, A. S., The Origin of Medical Terms, London, Bailliere, Tindall and Cox, 1949.

SOEMMERRING, S. T. VoN, cited by Limborgh, 1964.

Starling, E. H., 'The influence of mechanical factors on lymph production', J. Physiol., 1894, 16, 224-67.

VIRChow, R., Cellular Pathology, trans. from the second German edition by Frank Chance, New York, de Witt, 1860.

Veslingius, The Anatomy of the Body of Man, trans. by Nich. Culpeper, London, 1653.

Yofrey, J. M. and CourTiCe, F. C., Lymphatics, Lymph and Lymphoid Tissue, London, Edward Arnold, 1956. 